\title{
APLIKASI ETOS KERJA DALAM BERBAGAI PROFESI
}

\author{
Sohari \\ IAIN Sultan Maulana Hasanuddin Banten
}

\begin{abstract}
Abstrak. Aplikasi Etos Kerja Dalam Berbagai Profesi. Sebagai agama yang seimbang Islam memberikan prinsip-prinsip yang penting untuk mengatur segala aspek kehidupan manusia, baik yang menyangkut peribadatan, sosial, ekonomi dan hukum. Dalam membahas muamalah Islam juga telah memberikan pedoman yang jelas dalam mencari dan mencapai keuntungan. Dalam jual beli Islam telah memberikan etos yang sangat baik yaitu seseorang harus melakukan jual beli dengan jalan yang dilakukan secara transparan dan dilakukan suka sama suka. Berkenaan dengan hal tersebut, menjadi sangat urgen bagi para pelaku bisnis muslim untuk mempelajari prinsipprinsip dasar dalam berbisnis dan berperilaku yang lainnya dengan cara mempunyai etos kerja yang baik yang diridhai oleh Allah SWT. Etos kerja yang baik ternyata akan berpengaruh bagi para pelaku ekonomi atau para karyawan, terutama dalam menghasilkan. Dalam kehidupan di masyarakat, orang-orang yang sukses dan berhasil dalam hidupnya adalah mereka yang senantiasa menggunakan waktunya untuk kegiatan yang bermanfaat dan selalu serius dalam mengerjakan sesuatu, mereka menganggap bahwa waktu adalah uang (time is money), Sebaliknya, orang-orang yang suka tidak berguna, tidak akan meraih kesuksesan bahkan ia akan tergilas oleh zaman. Oleh karena itu, seorang muslim selayaknya mengeluarkan segala kemampuannya untuk mencari rezeki dengan sekuat tenaga. Akan tetapi, rezeki yang diusahakannya untuk mencari rezeki haruslah halal, tidak mengutamakan penghasilan yang banyak semata, tanpa mengindahkan antara yang telah ditetapkan, tentu saja, pekerjaan apapun tidak dilarang selama tidak bertentangan dengan syari'at Islam. Dalam bekerja, ia menggunakan tangannya atau kemampuannya serta sesuai pula dengan keahliannya, Bekerja dengan menggunakan tangan dan kemampuan sendiri sebagaimana dijelaskan dalam hadis di atas adalah pekerjaan yang paling baik.
\end{abstract}

Kata Kunci: Etos Kerja, Profesi.

Abstract. The Applications of Work Ethic in Different Professions. Islam as a balanced religion gives the principles that are important to regulate all aspects of human life, both concerning worship, social, economic and legal. To discus, muamalah Islam has also give a clear guidance to find and achieve the profit. In trading, Islam has given a very good ethos that a person who buy and sale must use a transparent mekanism and do as they liked. In this regard, it becomes extremely urgent for Muslims business to learn the basic principles of doing business and others behave in a way to have a good work ethic which is blessed by Allah SWT. Good work ethic turned out to be devastating for the economic agents or employees. Mainly in produce, in the life of society, people who are successful and succeed in life are those who constantly use their time for activities that are beneficial and are always serious in doing something, they assume that time is money. In contrast, people who love useless, will not succeed even he 
will be crushed by the times. Therefore, a Muslim should expend all his ability to seek a job with a vengeance. However, that provision must be earned to seek sustenance kosher, do not put a lot of income alone, without regard to the established, of course, any kind of work is not prohibited as long as not contrary to the Islamic shariah. In the work, he uses his or her ability and in accordance also with expertise, working by hand using their own capabilities as described in the above hadith is the most excellent work. Key words: work ethic, profession. 


\section{PENDAHULUAN}

Islam sebagai agama yang akan membawa manusia kepada kebahagiaan manusia di dunia dan akhirat, dalam aplikasinya mempunyai peraturan dan cara-cara yang tertentu, baik dalam aplikasi ibadah mahdhah (ibadah yang sudah ditentukan cara-caranya), seperti shalat, zakat, puasa dan Haji), juga dalam ibadah ghair mahdhah, (ibadah yang tidak ditentukan cara-caranya dalam al-Qur'an dan Hadits), seperti bekerja, berbisnis dan aktifitas lainnya.

Sebagai agama yang seimbang Islam memberikan prinsip-prinsip yang penting untuk mengatur segala aspek kehidupan manusia, baik yang menyangkut peribadatan, sosial, ekonomi dan hukum. Dalam membahas muamalah Islam juga telah memberikan pedoman yang jelas dalam mencari dan mencapai keuntungan. Dalam jual beli Islam telah memberikan etos yang sangat baik yaitu seseorang harus melakukan jual beli dengan jalan yang dilakukan secara transparan dan dilakukan suka sama suka.

Berkenaan dengan hal tersebut, menjadi sangat urgen bagi para pelaku bisnis muslim untuk mempelajari prinsip-prinsip dasar dalam berbisnis dan berperilaku yang lainnya dengan cara mempunyai etos kerja yang baik yang diridhai oleh Allah SWT.

\section{JUAL BELI DAN HAK PILIH}

Jual beli merupakan salah satu bentuk mu'amalah yang dibahas dan diatur dalam syari'at Islam. Jual beli ini merupakan manivestasi dari manusia sebagai makhluk sosial. Kebutuhan manusia tidak mungkin dapat dipenuhi sendiri tanpa bantuan orang lain; Jual beli itu sudah ada jauh sebelum Nabi Muhammad saw. diutus menjadi rasul; hanya saja orang-orang pada masa Jahiliyah menyamakan jual beli dengan riba; Mengetahui Nabi Muhammad saw. Allah SWT. Membantah anggapan yang demikian itu dengan menurunkan wahyu yang mengharamkan riba dan menghalalkan jual beli (Abu Bakar, 1995). Hal ini sebagaimana dijelaskan dalam surat Al-Baqarah, ayat: 275. 


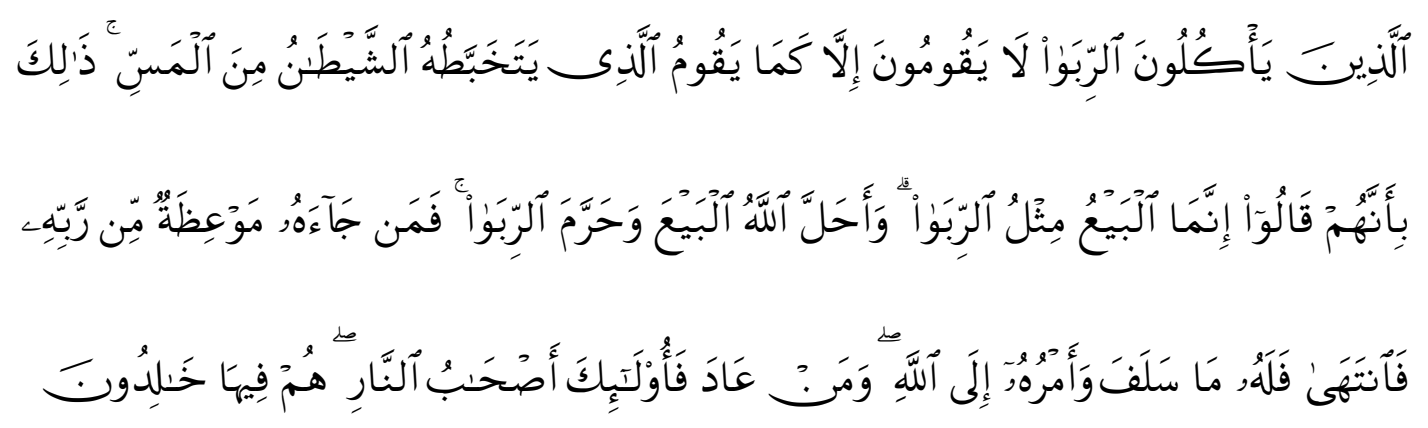

Orang-orang yang makan (mengambil) ribatidak dapat berdiri melainkan seperti berdirinya orang yang kemasukan syaitan lantaran (tekanan) penyakit gila. keadaan mereka yang demikian itu, adalah disebabkan mereka Berkata (berpendapat), Sesungguhnya jual beli itu sama dengan riba, padahal Allah Telah menghalalkan jual beli dan mengharamkan riba. orang-orang yang Telah sampai kepadanya larangan dari Tuhannya, lalu terus berhenti (dari mengambil riba), Maka baginya apa yang Telah diambilnya dahulu (sebelum datang larangan); dan urusannya (terserah) kepada Allah. orang yang kembali (mengambil riba), Maka orang itu adalah penghuni-penghuni neraka; mereka kekal di dalamnya. (Ash-Shiddieqi, 1990).

Agar tidak dilumuri oleh praktek kotor dalam jual beli yang halal (suci) itu, maka Allah mengutus Nabi Muhammad saw. Sebagai Rasul-Nya untuk memberikan tuntunan praktis terhadap pembeli dan penjual, serta tentang barang-barang yang boleh diperjual-belikan dan yang barang-barang yang dilarang diperdagangkan. Beliau juga menjelaskan kepada ummatnya tentang usaha yang baik (Abu Bakar, 1995).

\section{Pekerjaan Yang Baik}

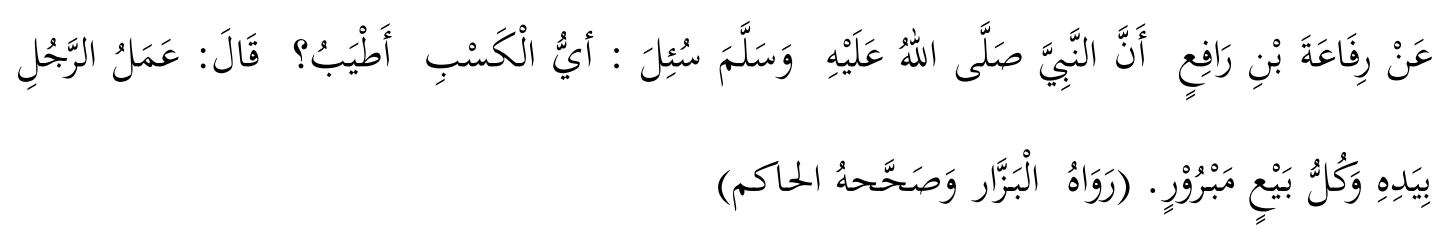

"Dari Rifa'ah bin Rafi' berkata bahwa Nabi SAW, ditanya, "Apa mata pencaharian yang paling baik?" Nabi menjawab "Seseorang bekerja dengan 
tangannya dan tiap-tiap jual beli yang bersih ". (Diriwayatkan oleh Bazzar disahkan oleh Hakim)

Hadits tersebut sebagai dalil (bukti) penetapan sesuatu yang disenangi oleh tabi'at hati manusia di antara usaha-usaha manusia itu. Hanya saja Rasulullah saw. Ditanya tentang usaha yang paling baik, yaitu usaha yang paling halal dan paling berkah; Mengusahakan usaha tangan dari jual beli yang bersih (dari tipu daya, menunjukan bahwa usaha tangan itulah yang paling baik. Yang diriwayatkan oleh AlBukhari yang akan dijelaskan nanti, dan Hadis itu menunjukan kebaikan perniagaan yang bersih dari tipu daya.

Di kalangan ulama terdapat perbedaan pendapat tentang usaha yang paling baik itu. Kata Al-Mawardi : Bahwa mata pencaharian pokok ialah: pertanian, perniagaan dan perindustrian. Menurut beliau bahwa yang paling sesuai dengan pendapat Imam Syafi'i adalah bhawa usaha yang paling baik itu adalah perdagangan. Katanya: Pendapat yang paling kuat menurut saya bahwa usaha yang paling baik itu ialah pertanian, karena lebih dekat kepada tawakkal kepada Allah. Beliau susul (untuk memperkuat argumentasinya) dengan sebuah hadis yang diriwayatkan oleh: AlBukhari dan Al-Miqdam yang bersambung sanadnya hingga Rasulullah saw. Beliau bersabda:

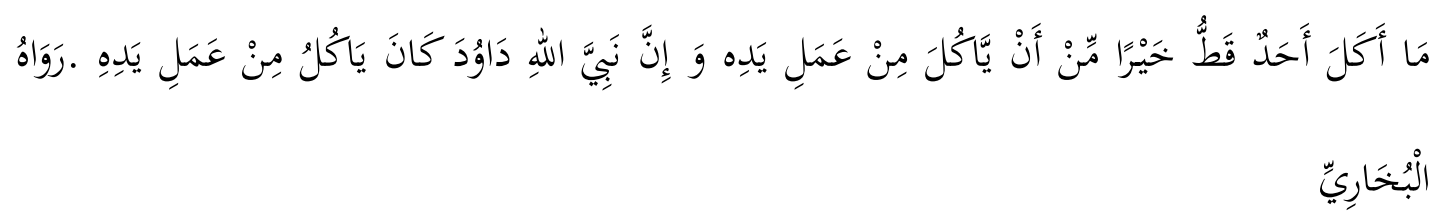

Seseorang tidak memakan suatu makananpun yang lebih baik daripada dia memakan hasil usaha tangannya sendiri; Dan sesungguhnya Nabi Allah Daud a.s. selalu memakan hasil usaha tanganya sendiri ; diriwayatkan oleh Al-Bukhari.

Kata Imam Nawawi: Bahwa sebaik-baiknya usaha itu adalah sesuatu yang dilakukan dengan sendiri. Jika usaha tangan itu adalah pertanian, maka itulah sebaikbaiknya usaha, karena semuanya mengandung usaha sendiri, di samping karena pertanian itu adalah tawakkal kepada Allah dan manfaatnya untuk umum, baik manusia maupun binatang melata dan burung. 
Kata Al-Hafidz Ibnu Hajar: Yang paling tinggi di antara usaha tangan itu adalah apa yang diperoleh dari harta kekayaan orang kafir melalui jihad dan itu adalah usaha Nabi Muhammad saw. Itulah seutama-utamanya usaha, karena usahanya itu demi untuk menegakan Agama Allah.

\section{Pelajaran yang terkandung dalam hadits tersebut}

Bila dicermati secara seksama Hadits tersebut mengandung beberapa pelajaran penting yang harus kita hayati, yaitu:

a. Dalam usaha mencari penghidupan kita pilih usaha atau mata pencaharian yang paling baik yang halal dan banyak berkahnya.

b. Ada dua usaha yang paling baik, yaitu semua usaha yang baik dlakukan dengan tangan sendiri, dan semua perdagangan yang bersih dari tipu menipu dan caracara lain yang tercela.

c. Dalam Hadis tersebut terkandung anjuran untuk rajin bekerja dan dilarang bermalas-malasan.

d. Dalam Hadits itu juga tersirat perintah untuk memakan sesuatu yang halal lagi baik.

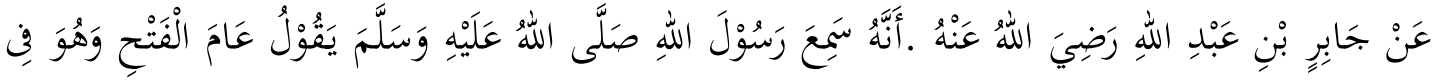

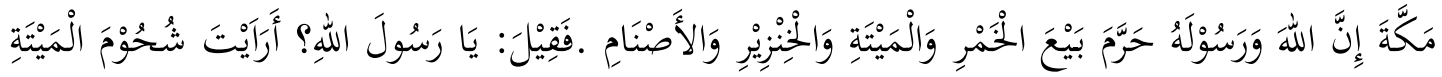

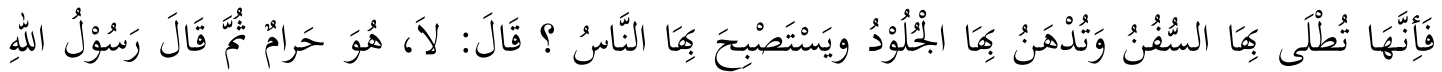

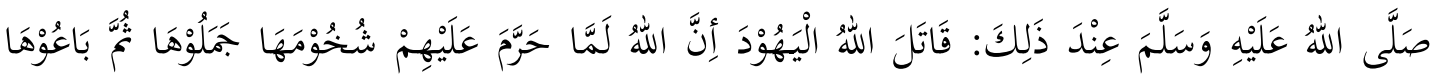

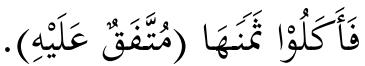

Dari Jabir bin Abdullah r.a. Sesungguhnya beliau mendengar Rasulullah saw. Bersabda pad atahun penaklukan Makkah sewaktu beliau berada di Makkah itu: Sesungguhnya Allah dan Rasul-Nya telah mengharamkan jual beli khamar (minuman keras), bangaki, daging babi dan berhala; Lalu beliau ditanya: Apa pendapatmu tentang lemak bangkai, karena sesungguhnya lemak bangkai 
dipakai untuk mencatat perahu, untuk meminyaki kulit dan orang mempergunakannya untuk pelita ?. Beliau bersabda: Tidak boleh; Dia haram; Kemudian Rasulullah saw. Bersabda pada waktu itu :Allah memerangi orang yahudi, karena sesungguhnya setelah Allah mengharamkan lemak bangkai kepada mereka, lalu mereka mencairkannya, kemudian mereka menjualnya lalu mereka memakan harganya. (Muttafaq 'alaih).

Dalam Hadits tersebut terdapat dalil (hukum) haramnya sesuatu yang disebutkan itu. Dikatakan bahwa alasan pengharaman jual beli tiga macam yang pertama (yaitu khamar, bangkai dan babi) adalah karena najis;Akan tetapi dalil-dalil yang menunjukan kenajisan kharam itu tidak jelas. Demikian kenajisan bangkai dan babi. Barang siapa yang menetapkan alasan haramnya karena najisnya, maka dia menetapkan huum haram jual beli segala sesuatu yang najis.

Sekelompok ulama berpendapat: boleh jual beli pupuk yang najis, ada yang mengatakan : hanya boleh bagi pembeli, tidak boleh bagi penjual; Tetapi pendapat dan alasan itu tidak tepat. Perbedaan pendapat ini semuanya hanyalah bagi orang yang menetapkan alasan larangan karena najisnya itu.

Yang paling nampak, bahwa tidak jelas dalil tentang alasan najisnya itu; Akan tetpi alasannya adalah haramnya itu. Itulah sebabnya Rasulullah saw. Setelah diharamkan lemak itu lepada mereka, lalu beliau menetapkan alasannya adalah karena haramnya itu sendiri beliau tidak menyebutkan alasan lain.

Ketahuilah: Bahwa tidak termasuk bangkai, rambutnya dan bulunya, karena rambut dan bulu tidak termasuk zat hidup dan tidak disebut bangkai; Ada yang mengatakan: Rambut itu mutanajjis dan dapat menjadi suci penyuciannya; Mengenai kebolehan penjualan buluhnya itu adalah menurut Jumhur ulama. Ada yang mengatakan kecuali rambut dan bulu tiga macam yang najis zatnya yaitu rambut dan bulu anjing, babi dan orang kafir.

Alasan pengharaman jual beli piutang berhala menurut kata orang adalah karena tidak ada manfaatnya yang dibolehkan. Ada yang mengatakan bahwa piutang berhala itu sudah dipecah, maka boleh dimanfaatkan pecahnya itu dan boleh dijual; Pendapat yang paling benar, tidak boleh menjual patung berhala itu berdasarkan 
larangan tersebut dan boleh mnejual pecahnya karena pecahnya itu bukan berhala lagi dan tidak ada alasan sama sekali untuk melarang perjualan pecahnya itu.

Tatkala Rasulullah saw. Mengungkapkan secara umum pengharaman jual beli bangkai maka pendengarannya mengira Rasulullah mentakhsiskannya dari yang umum itu sebagian bangkai; Lalu orang bertanya: Apa pendapatmu tentang lemak bangkai itu. Maksud orang itu: Jelaslah kepadaku Ya Rasulullah tentang lemak-lemak itu; Apakah lemak bangkai yang bermanfaat itu. Lalu Rasulullah saw. Menjawab: sesungguhnya lemak bangkai itu haram dan beliau menjelaskan kepadanya bahwa lemak bangkai itu tidak keluar hukum haram itu.

Dlomir huwa dalam sabdanya "Huwa haramun" itu mungkin kembali kepada jual beli yang berarti jual beli lemak bangkai itu haram dan inilah yang paling jelas karena pembicaraan dalam hadis tersebut adalah tentang jual beli itu dan berdasarkan Hadits yang diriwayatkan oleh Imam Ahmad; Dalam Hadits riwayat Ahmad terdapat matan sebagai berikut:

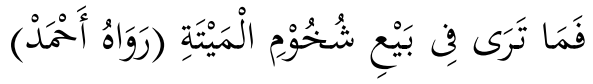

"Lalu apa pendapatmu tentang jual beli lemak bangkai itu? (H.R. Ahmad).

Mungkin juga dlomir "huwa" itu adalah untuk pemanfaatannya yang ditunjukan padanya dengan ucapan penanya "karena sesungguhnya lemak bangkai itu dipergunakan untuk mencatat perahu dan seterusnya Kebanyakan ulama menafsirkan "huwa" dengan pemanfaatannya itu, Kata mereka: Tidak boleh dimanfaatkan sedikitpun dari bangkai itu selain kulitnya apabila sudah disamak berdasarkan yang sudah dikemukakan dalam permulaan (jilid) kitab Hadits Tarbiyah ini. Dalil yang menjelaskan samak kulit itu mentakhsiskan keumuman itu. Dan itu berdasarkan pendapat bahwa kembalinya dlomir itu adalah kepada pemanfaatan kulit bangkai; Barang siapa yang berkata bahwa dlomir itu kembali kepada jual beli maka dia berdasarkan dalil ijma 'ulama tentang kebolehan pemberian makanan bangkai kepada anjing sekalipun anjing pemburu bagi orang yang memanfaatkan anjing pemburu itu.

Al-Qadli 'Iyad mengutip pendapat yang sama dari Imam Malik, kebanyakan ulama Maliki, dari Abu Hurairah, kawannya dan Al-Laits. Yang memperkuat 
kebolehan pemanfaatan lemak bangkai ialah Hadis yang diriwayatkan oleh Ath Thahawi bahwa Rasulullah saw. Ditanya tentang tikus yang jatuh kedalam samin (minyak) lalu beliau bersabda:

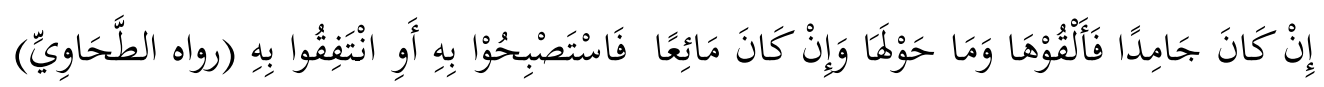

Jika minyak (samin) itu beku maka buanglah tikus itu bersama sesuatu (samin) di sekitarnya yang dikenai tikus itu; Dan jika samin itu cair maka jadikanlah minyak itu sebagai pelita atau memanfaatkanlah (samin) yang mutanajjis itu;

Kata Ath Thahawi; perawi-perawi dalam sanad Hadits tersebut, orang-orang yang terpercaya. Telah diriwayatkan juga tentang minyak yang kejatuhan tikus ini dari sekelompok ulama sahabat; Di antaranya: Ali bin Abi Thalib r.a. Ibnu Umar r.a dan Abu Musa, dari sekelompok ulama Tabi'in seperti Al-Qasim bin Muhammad, dan Salim bin Abdullah. Inilah Hadits yang jelas sebagai dalil tentang pemanfaatan sesuatu yang dikenai najis (mutanajjis).

Mengenai pembedaan antara pembangunan benda atau sesuatu najis dan pemanfaatannya, tidak ada dalilnya akan tetapi hanya berdasarkan pendapat murni; Sedang mengenai sesuatu yang terkena najis, jika mungkin dapat disucikan maka tidak ada bantahan tentang kebolehan penjualnya, dan yang tidak mungkin penyuciannya maka haram penjualannya; dan yang tidak mungkin penyuciannya maka haram penjualannya, dan yang tidak mungkin penyuciannya maka haram penjualannya; Demikian kata ulama Al Hadawiyyah dan Ahmad bin Hambal. Dalam Hadits tersebut terdapat dalil bahwa apabila sesuatu itu haram diperjual belikan maka haram pula harganya dan sesungguhnya setiap hillah (tipu muslihat) yang menyampaikan kepada penghalalan yang di haramkan, maka batil. Dalam Hadits tersebut terkandung beberapa pelajaran penting yang harus diperhatikan, yaitu:

1. Allah dan Rasul-Nya, sudah melarang jual beli khamar, bangkai, babi dan patung berhala; Berarti orang-orang yang memperjual belikan empat macam benda itu berdosa dan menjerumuskan orang dalam perbuatan dosa.

2. Larangan pemanfaatan semua yang diharamkan untuk apapun sekalipun sekedar untuk melicinkan kulit atau sebagai pelita. 
3. Semua yang dilarang untuk dijual belikan maka tidak boleh dimanfaatkan harganya.

4. Semua usaha merubah zat yang haram menjadi bentuk lain seperti pemberian nama lain bagi khamar berwujud bakso bagi daging babi dan pembulatan abon dari bangkai, tetapi haram dimakan.

Untuk menambah dalam pemahaman kita tentang larangan pemanfaatan sesuatu yang terlarang marilah kita memperhatikan Hadits nomor 4 bab jual beli ini.

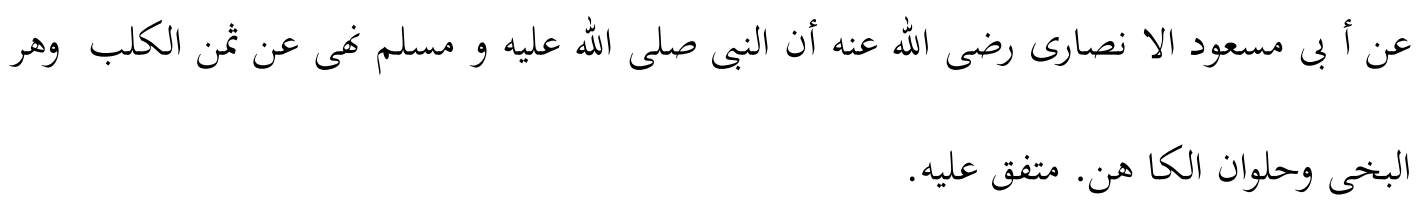

Dari Abu Mas'ud Al-Anshari r.a (beliau) berkata : Sesungguhnya Nabi Muhammad saw. Telah melarang pemanfaatan harga anjing, upah pezina (pelacur) dan upah tukang tenung. Muttafaq 'alaih.

Pada dasarnya larangan itu memberikanpengertian penghargaan sesuatu yang terlarang itu; Berarti Hadits tersebut menunjukan haramnya tiga macam yang disebutkan dalam hadits tersebut yaitu:

a. Haram pemanfaatan harga anjing, karena anjing itu haram dimakan. Hanya saja Ath' dan An Nakha'i mengecualikan anjing pemburu, berdasarkan Hadits yang diriwayatkan oleh An-Nasai dari Jabir, Beliau berkata:

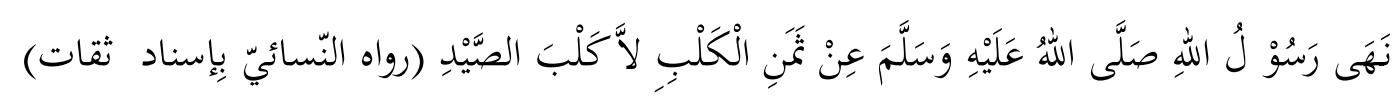

Rasulullah saw. Melarang pemanfaatan harga anjing selain anjing pemburu.

Diriwayatkan oleh An-Nasa'i. dengan sanad yang terpercaya.

b. Haram pemanfaatan upah perbuatan perzinaan atau pelacuran, karena berzina dan melacur itu terlarang.

c. Larangan pemanfaatan upah tukang, karena perbuatan itu juga terlarang. 


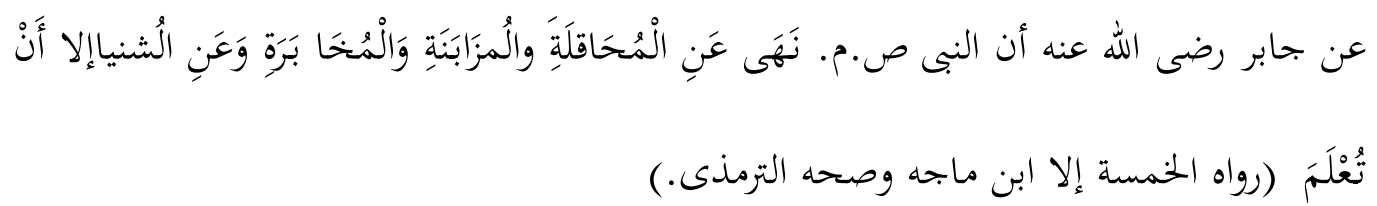

Dari Jabir r.a. (beliau berkata): Sesunguhnya Nabi saw. Melarang muhaqalah (penjualan tanaman atau bijian dengan borongan), muza-banah (penjualan dengan buatan), mukha-barah (sistem ijon), Tsunayyah (penjualan barang dengan pengecualian sebagian) kecuiali diketahui; Diriwayatkan oleh :Al Khamsah (lima perawi) selain Ibnu Majah; Jadi hanya oleh : Ahmad, Abu Daud, At-Trimidzi,An Nasa'i dan dinilai shahih oleh At-Trimidzi.

Hadits tersebut memuat (menjelaskan) tentang empat bentuk jual yang terlarang yaitu:

1. Larangan Muhaqalah. Jabir menjelaskan pengertiannya: bahwa Muhaqalah itu ialah jual beli oleh seseorang kepada orang lain dengan seratus takaran sebanyak enam belas kali atau seratus dua puluh kati gandum . (satu kati = 8 once). Abu 'ubaidah menafsirkannya bahwa Muhaqalaq itu ialah jual beli bahan makanan yang masih dibulirnya; Imam Malik menjelaskannya bahwa Muhaqalah itu ialah upah penggarapan sawah dengan sebagian hasil garapannya itu.

2. Larangan Muzabanah. Ibnu Umar menjelaskan pengertiannya: Bahwa Muzbanah itu jual beli kurma basah dengan kurma kering dengan takaran dan jual beli anggur basah dengan anggur kering dengan takaran ; Imam Syafi'i meriwayatkannya itu dari Ibnu Umar r.a. dalam kitab Al-Um; Beliau mengatakan: Bahwa penafsiran Muhaqalah dan Muzabanah dalam HaditsHadits itu mungkin dari Rasulullah saw. Dan mungkin juga dari para sahabat yang meriwayatkannya. Alasan larangannya ialah karena mengandung riba sebab tidak diketahui persamaan jumlahnya.

3. Larangan Muhabarah, ialah dari muzara'ah; Sedang muzara'ah itu ialah penggarapan tanah (sawah) dengan paron hasilnya; mengenai muzara'ah ini akan dibicarakan pada babnya sendiri. 
4. Larangan Tsunayyah (pengecualian sebagian barang) kecuali diketahui jumlahnya. Caranya ialah penjualan sesuatu dengan pengecualian sebagiannya; Akan tetapi jika sebagian itu diketahui jumlahnya, maka jual belinya; Misalnya jual beli beberapa pohon kayu atau pohon anggur dengan pengecualian sebatang tertentu, maka cara semacam itu benar dan sah. Kata mereka (ulama): Seandainya penjualnya berkata : kecuali sebagian itu belum diketahui dengan pasti.

Menurut Zhohir Hadits tersebut bahwa apabila diketahui jumlah yang dikecualikan itu maka sah secara mutlaq. Ada yang berkata: Tidak sah pengecualian sesuatu lebih dari sepertiga. Larangan pengecualian sebagian itu adalah karena tidak diketahui jumlah yang dikecualikan itu; Sedang sesuatu yang diketahui jumlahnya, maka keluar dari larangan tersebut.

Untuk menambah pengetahuan kita tentang system jual beli yang dilarang itu baiklah kita perhatikan Hadits berikut ini:

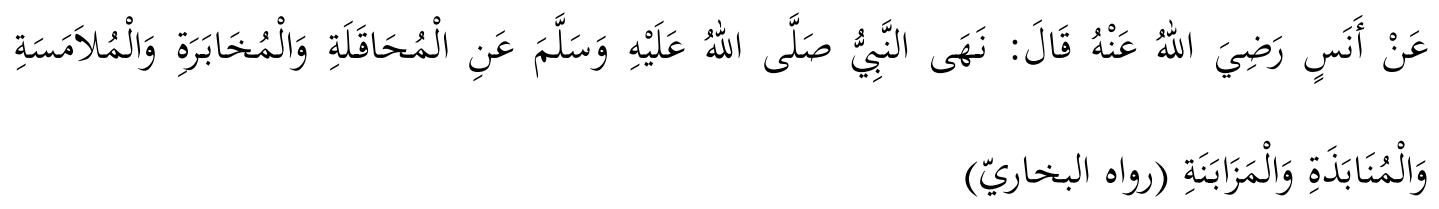

Dari Anas r.a. beliau berkata: Rasulullah saw. Melarang Muha-qalah, Mukhadlarah, Mula-masalah dan muna badzah dan muza banah. (H.R. AlBukhari).

Hadits tersebut menjelaskan tentang lima sistem jual beli yang terlarang, yaitu:

1. Larangan Muhaqalah yaitu jual beli tanaman atau bijian dengan sistem borongan jika tidak diketahui jumlahnya.

2. Mukhadlarah ialah jual beli buah-buahan dan tanaman yang masih di pohon sebelum matang (masak). Ulama berselisih pendapat tentang buah-buahan atau tanaman yang sah dijual belikan itu. Menurut sekelompok ulama: jika sudah sampai batas umur pemanfaatannya (sudah baik dipanen) misalnya sudah keras bijinya maka sudah jual belinya. Ada yang mengatakan : jika masa panennya sudah diketahui dengan pasti, maka sudah sah jual belinya. Jika 
belum, maka tidak sah jual belinya. Jika baru sebagiannya yang baik dipanen sedang sebagiannya belum baik dipanen, maka tidak sah jual belinya.

3. Larangan Mulamasah (jual barang dengan berdasarkan rabaan saja tanpa dilihat barangnya). Mengenai mula-masalah ini dijelaskan oleh hadits yang diriwayatkan oleh Al-Bukhari dari Az-Zuhri. Bahwa Mulamasah itu ialah rabaan seseorang terhadap pakaian pada siang hari atau malam hari lalu ditentukan harganya berdasarkan rabaan itu tanpa melihat pakaian itu. AnNasai'i meriwayatkan Hadits dari Abu Hurairah bahwa pengertian malmasalah itu ialah dengan cara penjual berkata kepada pembeli: saya jual kepada engkau pakaianku ini dengan pakaianmu dan masing-masing dari keduanya tidak saling melihat dahulu pakaian itu tetapi hanya merabnya saja.

4. Larangan Munabadzah. Mengenai munabadzah ini dijelaskan oleh Hadits yang diriwayatkan oleh Ibnu Majah dari Sufyah dari Az-Zuhri; Bahwa Munabadzah itu ialah seseorang berkata kepada yang lain: lemparkan apa yang ada padamu kepada saya dan saya akan melempar apa yang ada padaku kepadamu. Juga dijelaskan Hadis yang diriwayatkan oleh An Nasa'i dari Abu Hurairah bahwa munabadzah itu ialah dengan cara seseorang berkata kepada kawannya: Saya melempar apa yang akan ada padaku dan kamu juga melempar apa yang ada padamu kepadaku lalu masing-masing membeli barang yang dilemparkan oleh kawannya itu tanpa diketahui oleh masing-masing dari keduanya jumlah atau besar kecil barang yang dilemparkan itu.

5. Muzabanah ialah jual beli dengan perbuatan atau jual beli anggur basah dengan anggur kering dengan takaran.

Berdasarkan kedua Hadits tersebut ada 7 macam sistem jual beli yang terlarang, yaitu:

a. Muhaqalah (jual beli tanaman atau bijian yang tidak diketahui jumlah dengan sistem borong).

b. Muzabanah (jual beli dengan berebutan atau jual beli anggur basah dengan yang kering dengan takaran)

c. Mukhabarah (jual beli dengan sistem ijon) 
d. Tsunayyah (jual beli sesuatu pengecualian sebagainya tanpa diketahui jumlah atau besar kecilnya yang dikecualikan itu).

e. Mukhadlarah (jual beli buahobuahan atau tanaman yang masih di pohon sebelum nampak baiknya dipanen).

f. Mulmasalah (jual beli berdasarkan rabaan saja, tanpa lihat barang)

g. Munabadzah (jual beli barang dengan saling melemparnya tanpa diketahui kuantitas dan kualitas apa yang dilempar itu).

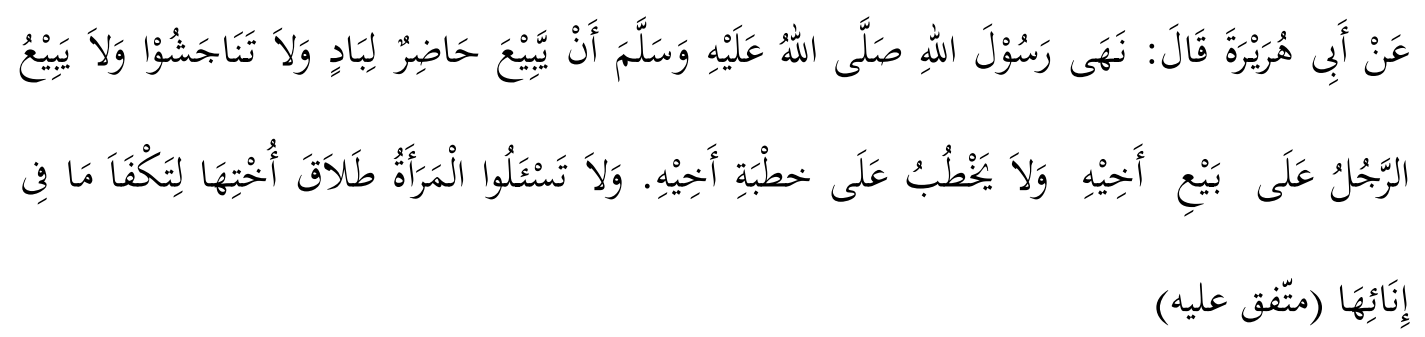

Dari Abu Hurairah r.a. beliau berkata: Rasulullah SAW, melarang orang kota menjualkan sesuatu untuk orang dusun, beliau melarang memuji-muji barang supaya laku dan mahal, tidak boleh seseorang menjual atas jualan saudaranya, tidak boleh dia meminang atas pinangan saudaranya, tidak boleh seorang wanita meminta thalaq saudaranya agar dia menguasai seisi rumahnya (Muttafaq 'alaih),

Penjelasan Hadis: Islam senantiasa mengajarkan kepada umatnya agar berusaha untuk memenuhi kebutuhan hidupnya, tidak dibenarkan seorang muslim berpangku tangan saja atau berdoa mengharapkan rizki datang dari langit tanpa pengiringnya dengan usaha. Namun demikian, tidak dibenarkan pula terlalu mengandalkan kemampuan diri sehingga melupakan pertolongan Allah SWT. Dan tidak mau berdoa kepada-Nya .

Banyak ayat Al-Qur'an yang menyuruh manusia untuk bekerja dan memanfaatkan berbagai hal yang ada di dunia untuk bekal hidup dan mencari penghidupan di dunia.

Dalam surat Al-Qashash ayat 77 Allah berfirman, yang artinya:

Dan carilah pada apa yang Telah dianugerahkan Allah kepadamu (kebahagiaan) negeri akhirat, dan janganlah kamu melupakan bahagianmu 
dari (kenikmatan) duniawi dan berbuat baiklah (kepada orang lain) sebagaimana Allah Telah berbuat baik, kepadamu, dan janganlah kamu berbuat kerusakan di (muka) bumi. Sesungguhnya Allah tidak menyukai orang-orang yang berbuat kerusakan.

Oleh karena itu, seorang muslim selayaknya mengeluarkan segala kemampuannya untuk mencari rezeki dengan sekuat tenaga, Akan tetapi, rezeki yang di usahakannya untuk mencari rezeki haruslah halal, tidak mengutamakan penghasilan yang banyak semata, tanpa mengindahkan antara yang telah ditetapkan, tentu saja, pekerjaan apapun tidak dilarang selama tidak bertentangan dengan syari'at Islam. Dalam bekerja, ia menggunakan tangannya atau kemampuannya serta sesuai pula dengan keahliannya, Bekerja dengan menggunakan tangan dan kemampuan sendiri sebagaimana dijelaskan dalam hadis di atas adalah pekerjaan yang paling baik, Dalam hadis lain pun ditanyakan;

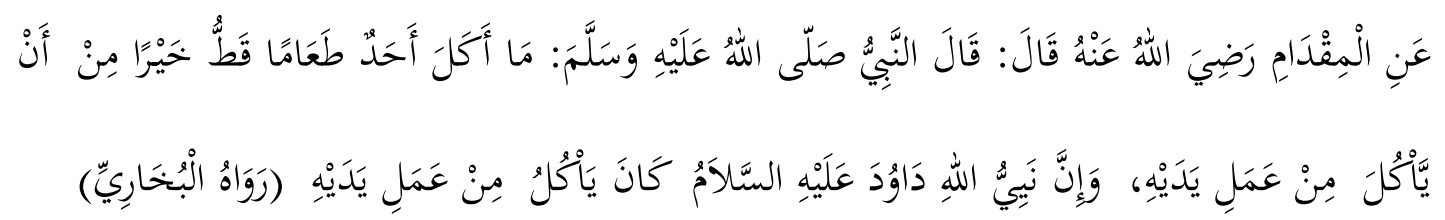

“Dari Miqdam, r.a. Nabi SAW, telah bersabda, "Tidaklah seseorang mkan sesuatu lebih baik dari pada makanan yang dihasilkan melalui sesuatu lebih baik dari pada makanan yang dihasilkan melalui tangannya (usahanya) sendiri. Dan sungguh Nabi Daud A.S. telah makan dari hasil tangannya. " (H. R. Bukhari). (Ya'qub, 2001).

Hadis ini lebih mempertegas tentang mulianya orang yang menggunakan tangan dan kemampuannya. Harta yang dihasilkan melalui kerja keras walaupun sedikit dipandang lebih berharga dari pada harta warisan atau pemberian orang lain.

Demikian pula ampunan Allah SWT, senantiasa menyertai orang yang keletihan dalam mencari rezeki, sebagaimana Rasulullah SAW bersabda :

$$
\text { من أ مسى كالا من عمل يده أ مسى مغفورا له. ( رواه أ حمد ) }
$$

"Barang siapa merasa letih di malam hari karena bekerja, maka ia malam itu ia di pahami." ( H. R. Ahmad). 
Selain itu, Islam pun menjamin dan melindungi mereka yang mau bekerja keras dan menyuruh para majikan untuk menghargai kerja keras orang yang bekerja padanya. Dalam sebuah hadis disebutkan:

$$
\text { أعطوالأجير أجره قبل أن يجف عرقه . ( رواه أ بو يعلى ) }
$$

“Berikanlah gaji kepada pekerja sebelum kering keringatnya." (H. R. Abu Ya'la).

Dalam kaitan ini Rasulullah SAW, pernah memberikan upah kepada petani sehingga mendapatkan separoh dari hasil tanaman yang digarap. Hal ini sesuai dengan Sabda Nabi :

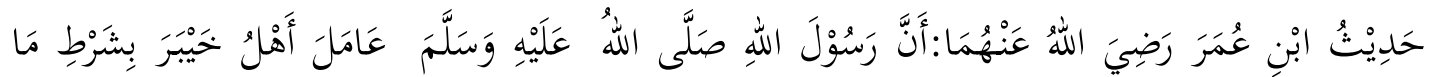

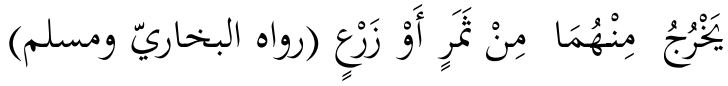

Diriwayatkan dari Ibnu Umar RA, dia telah berkata: "Sesungguhnya Rasulullah SAWS pernah memberi pekerjaan kepada penduduk Khaibar dengan upah separuh hasil buah-buahan atau tanaman yang dikerjakan" (H.R. Bukhari dan Muslim). (Mahalli, 2004).

Di antara hikmah dari rezeki yang dihasilkan melalui tangan sendiri. adalah terasa lebih nikmat dari pada hasil kerja orang lain, Juga akan menumbuhkan hidup hemat karena merasakan bagaimana payahnya mencari rezeki, Selain itu, ia pun tidak akan lagi menggantungkan hidupnya kepada orang lain, yang belum tentu selamanya ridha dan mampu membiayai hidupnya.

Dalam Hadis di atas pun dinyatakan bahwa penjualan dengan cara yang baik, juga dikategorikan sebagai pekerjaan paling baik, yaitu tidak hanya mengutamakan keuntungan semata sehingga melanggar etika kejujuran dan melanggar rambu-rambu agama, Dia harus ingat bahwa perbuatannya akan dipertanggungjawabkan di hadapan Allah kelak, Dengan demikian, dia tidak mengurangi timbangan, berbohong, menipu, dan lain-lain. Tujuan dengan bukan hanya mencari keuntungan, tetapi juga membantu memenuhi kehidupan orang lain, dan harta yang dihasilkannya tiada lain untuk bekal hidup di dunia dalam rangka mengabdi kepada-Nya. 
Menurut Imam Al-Ghazali, manusia dalam hubungannya dengan kehidupan dunia akhirat sebagai pada tiga golongan.

a. Orang-orang yang sukses atau menang, yakni mereka yang lebih menyibukkan dirinya untuk kehidupan di akhirat dari pada kehidupan dunia.

b. Orang-orang yang celaka, yakni mereka yang lebih menyibukan dirinya untuk kehidupan di dunia dari pada kehidupan di akhirat.

c. Orang yang berada di antara keduanya, yakni mereka yang mau menyeimbangkan antara kehidupan di dunia dan kehidupan di akhirat.

Al-Faqih Abu Laits Samarqandi, mengutip pendapat seorang ahli hikmah, "Para pedagang yang tidak memiliki ketiga sifat di bawah ini akan menderita kerugian dunia akhirat;

a. Mulutnya suci dari bohong/ laghuwa (main-main) bergurau dan sumpah.

b. Hatinya suci dari penipuan, khianat, dan diri.

c. Jiwanya selalu memelihara shalat jum'at, sahalat berjamaah., selalu menimba ilmu dan mengutamakan rida Allah SWT, dari pada lainnya .'

Tentu saja tidak hanya berjual beli yang harus diperhatikan kehalalannya dan kebersihannya, tetapi juga dalam setiap kasab (usaha) hendaknya menjadikan kehalalan dan kebersihan sebagai standar utama dalam mencari rezeki karena bagaimanapun juga, Allah SWT akan meminta pertanggung jawaban kelak di akhirat.

Menurut Al-Faqih Abu Laits Samarqandi; orang yang menginginkan (usaha, harta) yang halal, ia harus memlihara lima perkara, yaitu:

a. Tidak menunda kewajiban Allah SWT, tidak menghambakan apalagi menghadapi kewajibannya sebagai hamba Allah.

b. Tidak ada seorang pun merasa dirugikan atau di anggap akibat usahanya.

c. Memelihara kehormatan (harga) diri dan keluarga, bukan semata menghimpun harta sebanyak-banyaknya.

d. Tidak membinasakan (memaksakan) diri dalam usaha. 
e. Tidak beranggapan bahwa rezekinya diperoleh dengan usahanya melainkan faktor langsung dari Allah SWT, sedangkan bekerja usaha semata hanya faktor penyebab datangnya rezeki."

Fiqh Al- Hadis:

Setiap orang Islam hendaknya menggunakan waktunya untuk bekerja guna memenuhi kebutuhan hidupnya, Dalam Islam, mata pencaharian yang di anggap paling baik adalah pekerjaan yang menggunakan tangan sendiri dan jual beli yang bersih dan halal.

Dalam setiap kasab (usaha), hendaknya setiap muslim menjadikan dan kebersihan sebagai standar utama, karena Allah SWT, akan meminta pertanggung jawabannya kelak di akhirat atau segala usaha/kasab dan perbuatan yang dilakukan manusia di dunia.

\section{LARANGAN MEMINTA-MINTA}

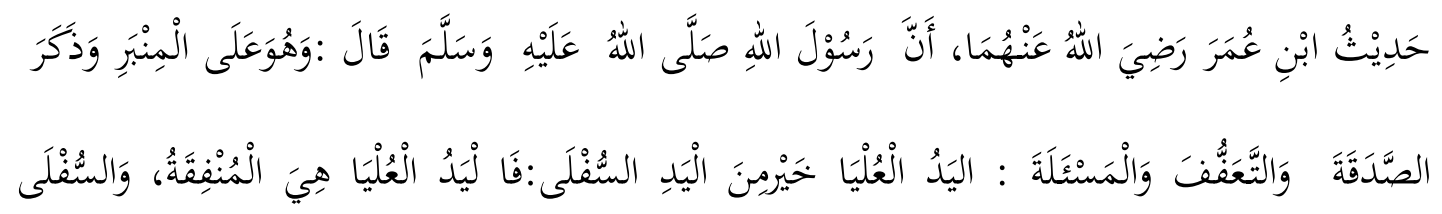

Umar r.a. berkata, "Ketika Nabi SAW, bersabda di atas mimbar dan menyebut sedekah dan meminta-minta beliau bersabda, " Tangan yang di atas lebih baik dari pada tangan yang di bawah, tangan yang diatas memberi dan tangan yang di bawah meminta. (H,R. Bukhari dan Muslim). (Baqi, 1996).

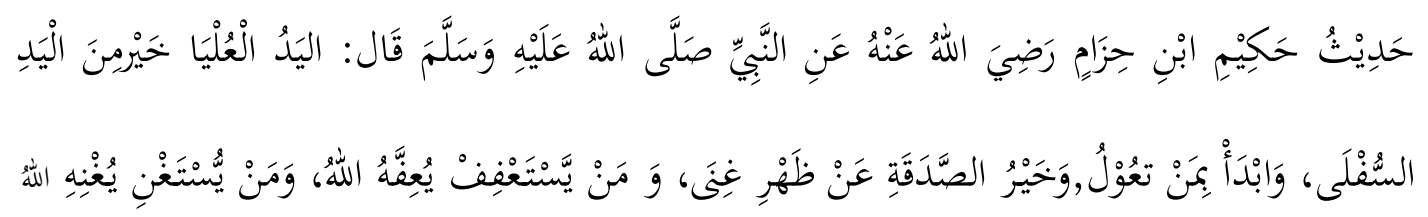

Hakim bin Hzam berkata, "Nabi SAW. Bersabda, "Tangan yang di atas lebih baik dari pada tangan yang di bawah dandahulukan keluargamu (orang-orang yang wajib kamu beri pelajaran), dan sebaik-baiknya sedekah itu dari kekayaan (yang berlebihan), dan siapa yang menjaga kehormatan diri (tidak meminta-minta), 86 
maka Allah akan mencukupinya, demikian pula siapa yang beriman merasa sudah cukup maka Allah akan membantu memberinya kekayaan." (Hadits Bukhari dan Muslim).

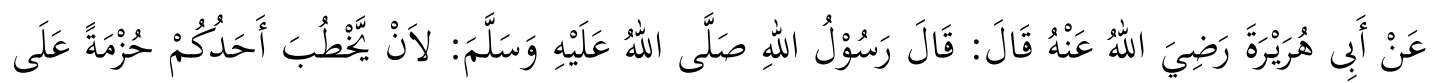

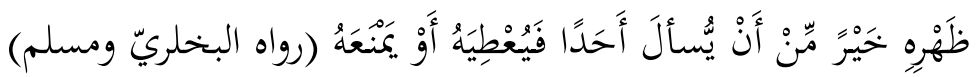

Abu Hurairah r.a berkata : Rasulullah Saw. Bersabda jika seorang itu pergi mencari kayu, lalu di angakt sedikit kayu di atas punggungnya (yakni untuk dijual di pasar) maka itu lebih baik bagimu dari pada minta kepada seseorangbaik di beri atau ditolak." (Diriwayatkan oleh Imam Bukhari dan Muslim).

Penjelasan Singkat :

Islam sangat mencela orang yang mampu untuk berusaha dan memiliki badan yang sehat, tetapi tidak mau berusaha, melainkan hanya menggantungkan hidupnya pada orang lain. Misalnya, dengan cara meminta-minta, Keadaan seperti itu sangat tidak sesuai dengan sifat umat Islam yang mulia dan memiliki kekuatan.

Sebagaimana diketahui bahwa mencari nafkah yang halal itu wajib bagi setiap muslim, maka setiap muslim hendaknya memperhatikan bidang dan lapangan profesi yang akan dipilihnya (Ya'kub, 2003).

Kenyataan menunjukkan bahwa apa yang dilakukan oleh sekelompok manusia terdapat pula sejumlah pekerjaan yang haram dan tercela yang bertentangan dengan etos kerja Islami, seperti judi (maisir), pelacuran, bisnis minuman keras dan sebagainya.

Dalam hubungan ini al-Qur'an dan al-Hadits sebagai sumber etos kerja Islami telah memberikan khitthah antara yang halal dan yang haram, antara yang terpuji dan yang tercela. Dalam Hadits riwayat Bukhari dan Muslim disebutkan:

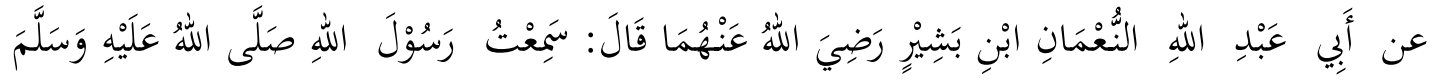

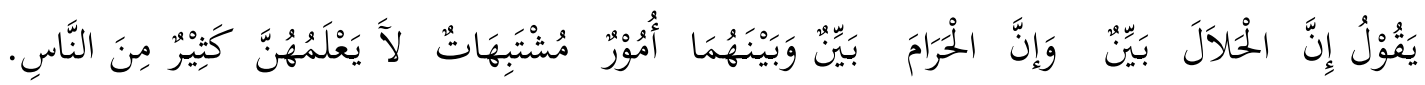




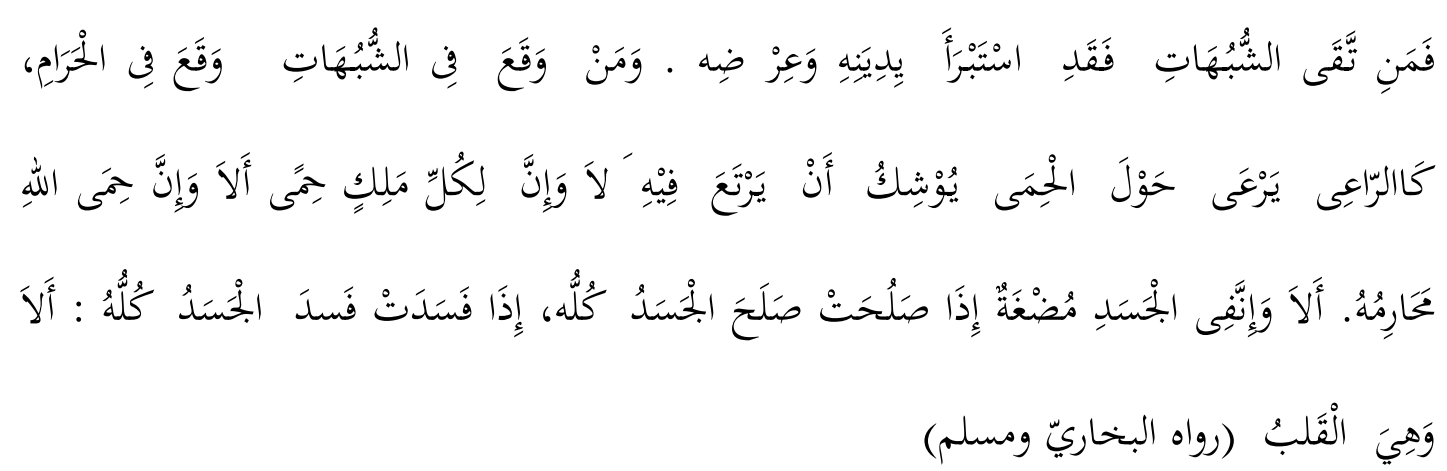

Dari Abdullah An Nu'man bin Basyir RA. Ia berkata: Aku mendengar Rasulullah SAW, bersabda: "Sesungguhnya yang halal telah jelas, yang haram telah jelas dan di antara keduanya banyak perkara syubhat (yang masih samara) yang kebanyakan manusia tidak mengetahui. Barang siapa berhati-hati terhadap hal yang syubhat, maka sesungguhnya dia telah menyelamatkan agama dan kehormatannya. Dan barang siapa terjerumus kepada hal-hal syubhat, maka ia telah terjerumus pada hal yang haram. Seperti seorang pengembala yang menggembala di sekitar daerah terlarang, maka hampir-hampir ia terjerumus ke dalamnya. Ketahuilah, bahwa tiap-tiap raja mempunyai larangan. Ketahuilah bahwa larangan Allah adalah apa-apa yang diharamkan-Nya. Ketauilah, bahwa di dalam tubuh ada segumpal daging, jika baik, maka baiklah seluruh tubuh, jika rusak, maka rusaklah seluruh tubuh, Ketahuilah, itulah hati" (H.R. Bukhari dan Muslim). (Nawawi, 2001).

Hadits di atas merupakan salah satu pokok Syari'at Islam. Abu Dawud As Sijistani berkata: Islam bersumber pada empat hadits," Dia sebutkan, di antaranya adalah hadits ini. Para ulama telah sepakat atas keagungan dan banyaknya manfaat hadits ini.

Kalimat "sesungguhnya yang halal telah jelas dan yang haram telah jelas, dan di antara keduanya banyak perkara syubhat (yang masih samara)" maksudnya segala sesuatu terbagi kepada tiga macam hukum. Sesuatu yang ditegaskan halkalnya oleh Allah, maka dia adalah halal, seperti firman Allah dalam Surat al-Maidah ayat 5:

Dihalalkan bagimu yang baik-baik. makanan (sembelihan) orang-orang yang diberi Al Kitab itu halal bagimu, dan makanan kamu halal (pula) bagi mereka. 
Menurut An-Nawawi seperti diterjemahkan olh Muhammad Thalib, menyebutkan bahwa sesuatu yang syubhat yaitu setiap hal yang dalil-dalinya masih dalam pembicaraan atau pertentangan; maka menjauhi perbuatan semacam itu termasuk wara'. Para ulama berbeda pendapat mengenai pengertian syubhat yang disyari'atkan Rasulullah SAW, pada hadits tersebut. Sebagian berpendapat bahwa hal semacam itu haram hukumnya berdasarkan sabda Nabi SAW. "barang siapa menjauhi yang syubhat, maka sesungguhnya ia telah menyelamatkan agamanya dan kehormatannya". Barang siapa tidak menyelamatkan agama dan kehormatannya, berarti dia telah terjerumus ke dalam perbuatan haram.

Salah satu hal yang dipandang masih samara-samar adalah orang yang suka minta-minta. Dengan demikian, seorang peminta-minta, yang sebenarnya mampu mencari kasab dengan tangannya, selain telah merendahkan dirinya, ia pun secara tidak langsung telah merendahkan ajaran agamanya yang melarang perbuatan tersebut. Bahkan ia dikategorikan sebagai kufur nikmat karena tidak menggunakan tangan dan anggota badannya untuk berusaha mencari rezeki sebagaimana diperintahkan syara'. Padahal Allah pasti memberikan rezeki kepada setiap makhlukNya berusaha.

Dalam ketiga hadis di atas dinyatakan secara tegas bahwa tangan orang yang di atas (pemberi sedekah) lebih baik dari pada tangan yang di bawah (yang diberi), Dengan kata lain, derajat pemberi lebih tinggi dari pada derajat peminta-minta. Maka seyogianya bagi setiap umat Islam yang memiliki kekuatan untuk memberi rezeki, berusaha untuk bekerja apa saja yang penting halal, walaupun suatu pekerjaan dipandang hina dalam pandangan manusia, seperti dicontohkan dalam hadis, yaitu pencari kayu, seseorang yang mencari dan mengikat kayu serta membawanya di atas punggungnya, Tentu saja, hasilnya tidak besar, tetapi pekerjaan ini lebih mulia dibandingkan para pengemis atau orang yang biasa menguntungkan hidupnya pada orang lain, yang mungkin mendapatkan hasil lebih banyak. Padahal yang diperoleh dengan cara seperti ini sama dengan mengumpulkan bara api. Sebagaimana sabda Rasulullah SAW :

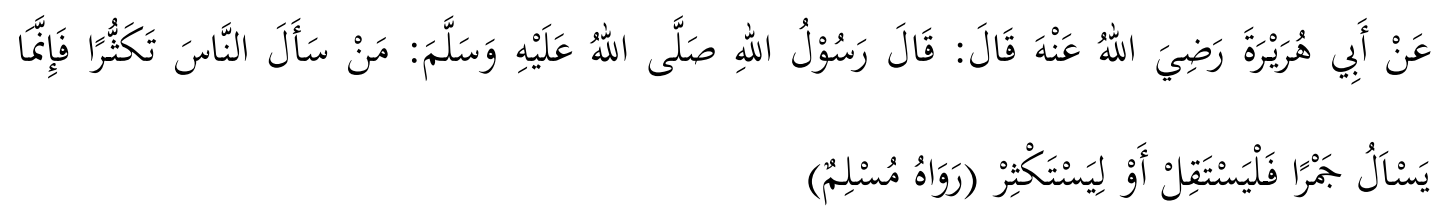


Abu Hurairah berkata bahwa rasulullah Saw. bersabda, "Barang Siapa yang meminta-minta untuk memperbanyak kekayaanya, ia tidak lain hanya memperbanyak bara api, maka terserah padanya apakah ia akan mengurangi atau memperbanyaknya. (H. R. Muslim).

Dalam hadis di atas pun disinggung tentang etika memberikan bantuan kepada orang lain, yaitu mengutamakan keluarga terdekat, kerabat terdekat, danseterusnya, Selain itu, barang yang akan diberikan haruslah merupakan rezeki lebih, Dengan kata lain, tidak mengutamakan memberi kepada orang lain sementara diri dan keluarganya kelaparan, dengan demikian, maka tidak boleh terlalu kikir ataupun terlalu berlebih-lebihan dalam memberikan sesuatu kepada orang lain.

Bagi orang yang selalu membantu orang lain, di samping akan mendapatkan pahala kelak di akhirat, Allah juga akan mencukupkan rezekinya di dunia. Dengan demikian, pada hakikatnya dia telah memberikan rezekinya untuk kebahagiaan dirinya dan keluarganya Karena Allah SWT. Akan memberikan balasan yang berlipat dan bantuan yang ia berikan kepada orang lain.

Orang yang tidak meminta-minta (percaya diri) dan tidak menggantungkan hidup kepada orang lain meskipun serba kekurangan, lebih terhormat dalam pandangan Allah SWT. Dan Allah akan memuliakannya dengan mencukupinya. Orang Islam harus berusaha memanfaatkan karunia yang diberikan oleh Allah SWT. Yang berupa kekuatan dan kemampuan dirinya untuk mencukupi hidupnya disertai doa kepada Allah SWT.

Adanya kewajiban berusaha bagi manusia, tidak berarti bahwa Allah SWT. Tidak berkuasa untuk mendatangkan rezeki begitu saja kepada manusia, tetapi dimaksudkan agar manusia menghargai dirinya sendiri dan usahanya, sekaligus agar tidak berlaku semena-mena atau melampaui batas.

Pemahaman Al- Hadis :

Tangan yang di atas yakni memberi sedekah lebih baik dari pada tangan yang di bawah, yang meminta-minta atau menggantungkan hidupnya pada orang lain. 
Dalam memberikan bantuan kepada orang lain, hendaknya mendahulukan keluarga (orang-orang yang wajib dinafkahi baik kerabat atau pun tetangga), sedangkan sedekah yang diberikan tersebut berasal dari kelebihan rezekinya.

Orang yang menjaga kehormatan diri, dengan berusaha untuk menghindari dari meminta-minta atau menggantungkan hidup pada orang lain, ia akan dicukupkan oleh Allah. Pekerjaan yang tampak hina dan hanya menghasilkan sedikit, akan lebih baik dan mulia dari pada hidup menggantungkan diri pada orang lain.

\section{Mu'min Yang Kuat Mendapat Pujian}

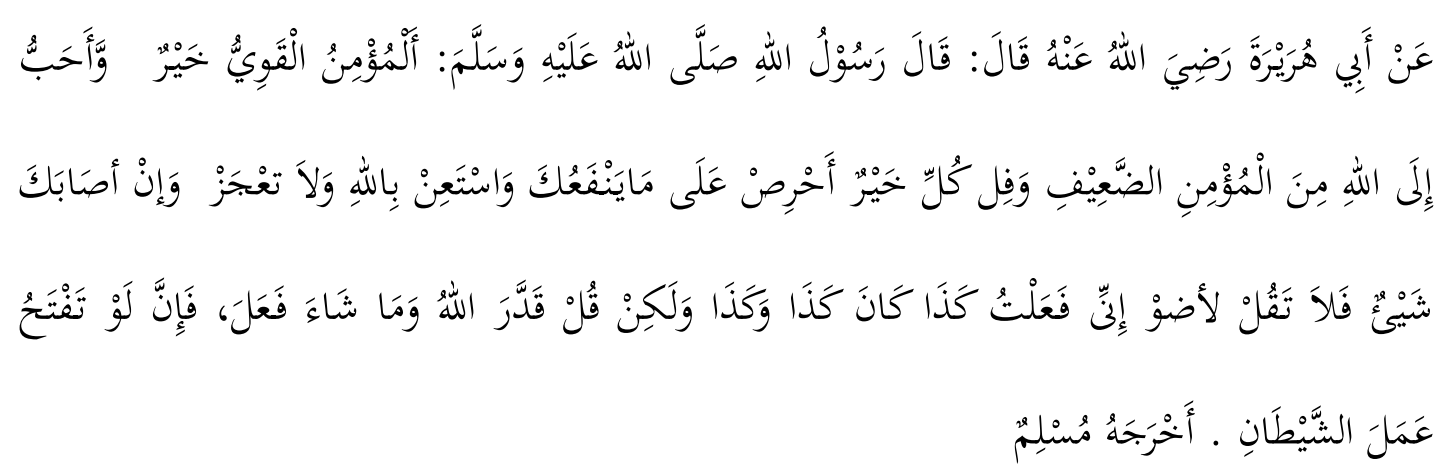

Abu Hurairah r.a. berkata bahwa Rasulullah Saw bersabda "Orang mukmin yang kuat lebih baik dan lebih di cintai Allah dari pada mukmin yang lemah dan dalam segala sesuatu, ia di pandang lebih baik, Raihlah apa yang memberikanmanfaat bagimu, Minta tolonglah kepada Allah, janganlah lemah! Kalau engkau tertimpa sesuatu, janganlah berkata , kalau aku berbuat begini, pasti begini dan begitu, tetapi katakanlah "Allah SWT. Telah menentukan dan Allah menghendaki aku untuk berbuat karena (kata) "kalau" akan mendorong pada perbuatan setan. (H. R. Muslim)

Penjelasan singkat

Hadis di atas mengandung tiga perintah dan dua larangan yang berikut ini:

a. Memperkuat Iman.

Keimanan seorang akan membawa kepada kemuliaan baginya, baik di dunia maupun di akhirat, Kalau keimananya kuat dan selalu diikuti dengan melakukan amal saleh, ia akan mendapatkan manisnya iman. Syaikh Abdur Razzaq bin Abdul Muhsin Al-'Abbad Al Badr dalam Asbab Ziyadati al-Imani wa nuqshanihi, 
yang diterjemahkan oleh Ahmad S Marzuki mengemukakan bahwa perkara yang paling diinginkan dan disukai serta saling bermanfaat adalah iman. Allah menunjukkan banyak jalan untuk meraih, memperkuat atau menambah iman seseorang. Jika seorang hamba menjalaninya, maka keyakinan dan keimanannya akan bertambah dan semakin kuat. Semua itu telah dijelaskan oleh Allah dalam Kitab-Nya dan oleh Rasul-Nya dalam sunah-sunnahnya (Razzaq, 2006).

Mempelajari ilmu yang bermanfaat yang bersumber dari Kitabullah dan Sunnah Rasulullah SAW.

1. Membaca dan merenungkan al-Qur'an al-Karim

2. Mengenal nama-nama Allah Paling Indah dan sifat-sifat-Nya Yang Paling Tinggi.

3. Memperhatikan sirah Nabi yang Mulia

4. Memperhatikan keindahan Ajaran Agama Islam

5. Membaca Sirah Salaf (Pendahulu) umat ini

6. Merenungkan ayat-ayat Kauniyah

7. Bersungguh-sungguh dalam mengerjakan, memperbanyak, dan menjaga Amal Shalih dengan ikhlas, mengharap wajah Allah Ta'ala.

Amalan dalam aktifitas manusia ada tiga hal, yaitu: 1) Amalan hati, 2) Amalan lisan, 3) Amalan anggota badan.

Menurut Ibnu Rajab, "Ilmu yang bermanfaat adalah menguasai nash-nash AlKitab dan As-Sunnah, memahami makna-maknanya. Mengambil atsar dari pasa Shahabat, tabi'in dan tabi't tabi'in yang berkaitan dengan makna-makna al-Qur'an dan Hadits, serta perkara-perkara yang berkaitan dengan halal, haram, zuhud, kelembutan hati (raqa'ib), dan berbagai pengetahuan lainnya.

Di samping itu juga bersungguh-sungguh dalam membedakan yang shahih dengan yang dhaif dan bersungguh-sungguh dalam memahami makna atsar-atsar tersebut. Ilmu yang seperti ini sudah cukup bagi orang yang berakal dan cukup menyibukkan orang yang mencari kesibukan dengan ilmu yang bermanfaat ini". 
Setiap orang memiliki tingkat keimanan yang berbeda-beda Ada yang kuat keimannya yang ditandai dengan sifatnya yang selalu berusaha untuk mengisi keimananya dengan berbagai amal yang diperintahkan oleh Allah SWT. Seperti memerintah kebaikan dan melarang kemungkaran, mengajarkan shalat, mengeluarkan zakat, memberi sedekah, dan lain-lain. Ada pula yang lemah imanya ia tidak mau mengerjakan kewajibannya sebagai orang beriman,seperti yang disebutkan di atas. Tentu saja, orang yang kuat imannya lebih baik dari pada orang yang lemah imannya. Hal ini karena orang yang kuat imannya akan berusaha untuk menjadikan segala aktivitas kehidupannya dalam kebaikan.

Telah disebutkan di atas pembahasan tentang sebab-sebab bertambahnya keimanan. Maka berikut ini akan dibahas mengenai sebab-sebab berkurangnya iman. Sebab, di samping terdapat hal-hal yang dapat menambah dan menumbuhkannya, juga terdapat hal-hal yang dapat mengurangi dan melemahkannya. Seorang muslim, dituntut untuk mengetahui hal-hal yang dapat menambah keimanan agar mampu melakukannya, juga dituntut untuk mengetahui hal-hal yang dapat mengurangi keimanan agar bisa menjauhinya. Hal ini dapat dilihat dari kata-kata berikut:

Aku mengenal kejelekan bukan untuk melakukan kejelekan itu, tetapi agar dapat menjauhinya. Barangsiapa yang tidak mengenal kejelekan manusia, ia akan terjerumus ke dalamnya.

Disebutkan dalam Ash-Shahihain dari Hudzaifah bin Al-Yaman ra bahwa dia berkata:

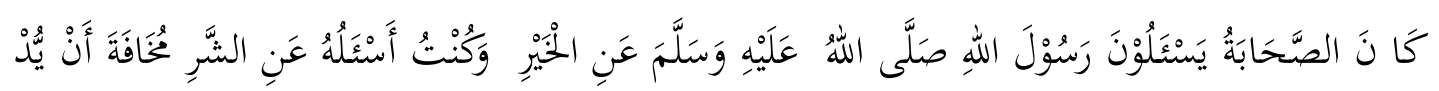

Dulu para sahabat bertanya kepada Rasulullah SAW tentang kebaikan, sedang saya bertanya kepada belkiau tentang kejelekan karena saya khawatir jika kejelekan itu menimpaku".

Ibnu Al-Jauzi berkata: "Mengenal kejelekan itu dalam rangka menghindarkan diri agar tidak terjerumus ke dalamnya. Jadi mempelajari sebab-sebab berkurangnya keimanan, mengenal hal-hal yang dapat melemahkannya, dan mengetahui cara-cara 
untuk melindungi diri dari hal-hal tersebut adalah sebuah keharusan yang harus diperhatikan. Bahkan, mempelajari perkara-perkara yang dapat mengurangi keimanan tidak kalah pentingnya dari pada mempelajari perkara-perkara yang dapat menambah keimanan.

Kuat dan lemahnya seorang mukmin, selain dapat dipahami dan perbuatan yang dilakukannya, dapat juga dipahami dalam realitas kehidupan Misalnya, dilihat dari segi kekuatan badan, ia tidak loyo, selalu tegar, dan lain-lain Seorang mukmin yang berbeda kuat dan menggunakan kekuatannya itu digunakan untuk beribadah dan membela agamanaya lebih baik dari pada mukmin yang lemah badannya sehingga tidak memiliki kekuatan untuk berjuang menegakan agama Allah.

Kekauatan dalam hadis di atas dapat juga di pahami dalam hal ekonomi atau kekayaan. Orang yang rajin berusaha sehingga memperoleh harta benda yang melimpah untuk digunakan bekal beribadah dan mengerjakan amal saleh lebih baik dari pada orang yang tidak mau berusaha sehingga kehidupannya susah.

Secara singkat dapat dijelaskan bahwa Rasulullah Saw. memerintahkan orang yang beriman untuk menghiasi keimananya dengan berbagai amal saleh serta memelihara badannya agar kuat, dan rajin berusaha sehingga kuat perekonomiannya. Tentu saja tetap berusaha untuk menjauhi segala bentuk kemaksiatan supaya mendapat kebahagiaan di dunia dan akhirat.

b. Perintah Untuk Memanfatkan Waktu

Rasulullah SAW, menginginkan agar umatnya mendapat kebahagiaan di dunia dan di akhirat, Oleh karena itu beliau memerintahkan umatnya untuk memanfaatkan waktu seefektif mungkin bagi kegiatan-kegiatan yang bermanfaat, baik untuk kehidupan di dunia maupun akhirat.

Banyak sekali aktivitas yang bermanfaat bagi kehidupan seorang mukmin, seperti mencari ilmu, membaca, bekerja mencari rezeki yang halal, berolah raga, memperbanyak amalan sunnah, dan lain-lain Oleh karena itu, jangan menghambur-hamburkan waktu membantu kegiatan yang tidak bermanfaat, bermalas-malasan, melamun, banyak menonton TV yang acarannya kurang bermanfaat, dan lain-lain. 
Dalam kehidupan di masyarakat, orang-orang yang sukses dan berhasil dalam hidupnya adalah mereka yang senantiasa menggunakan waktunya untuk kegiatan yang bermanfaat dan selalu serius dalam mengerjakan sesuatu, mereka menganggap bahwa waktu adalah uang (time is money), Sebaliknya, orang-orang yang suka tidak berguna, tidak akan meraih kesuksesan bahkan ia akan tergilas oleh zaman. Pepatah Arab menyatakan:

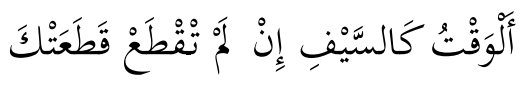

"Waktu itu bagaikan pedang, jika kamu tidak memanfaatkannya (menggunakannya untuk memotong), ia akan memotongmu (mengilasmu)."

Jadi kita sebagai insan yang berfikir hendaknya pandai-pandai menggunakan waktu yang telah diberikan oleh Allah SWT, untuk diaplikasikan dalam perbuatan yang bermanfaat dan berhasil guna, sebab, jika kita terlena dengan waktu maka kita akan ketinggalan.

Iqbal dalam Asrar Al-Khudi berkata, " Berhenti tidak ada tempat untuk jalan ini dan sikap lamban berarti mati, Mereka yang bergerak, akan maju ke muka, sedangkan mereka yang menunggu sekalipun sejenak pasti tergilas.

\section{Memohon Pertolongan Allah SWT.}

Manusia hanyalah diwajibkan untuk beriktia, sedangkan yang memutuskan keberhasilannya adalah Allah SWT. Orang mukmin sangat ditekankan untuk memperbanyak doa agar Allah SWT. Dengan berdo'a kepada Allah insya Allah akan mengabulkan do'a kita. Namun sekali lagi kita harus selalu berusaha, sesuai Firman Allah yang tercantum dalam Surat Ar-Ra'du ayat 11:

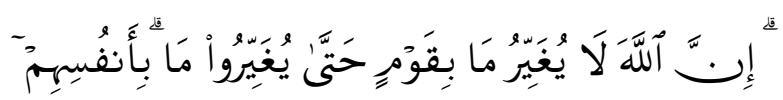

"...Sesungguhnya Allah tidak merobah keadaan sesuatu kaum sehingga mereka merobah keadaan yang ada pada diri mereka sendiri.

Di samping kita berusaha jangan lupa berdo'a kepada Allah, sejalan dengan Firman Allah dalam surat al-Fatihah ayat 5: 


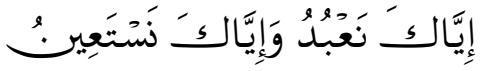

"Hanya Engkaulah yang kami sembah, dan Hanya kepada Engkaulah kami meminta pertolongan"

Kata $N a$ 'budu diambil dari kata 'ibaadat: kepatuhan dan ketundukkan yang ditimbulkan oleh perasaan terhadap kebesaran Allah, sebagai Tuhan yang disembah, Karena berkeyakinan bahwa Allah mempunyai kekuasaan yang mutlak terhadapnya. Nasta'iin (minta pertolongan), terambil dari kata isti'aanah: mengharapkan bantuan untuk dapat menyelesaikan suatu pekerjaan yang tidak sanggup dikerjakan dengan tenaga sendiri.

Dalam ayat tersebut pernyataan beribadah disejajarkan dengan pertolongan memohon pertolongan. Orang-orang yang hanya beribadah saja kepada-Nya, namun tidak pernah memohon pertolongan keimananya, masih dipertanyakan. Ini karena dia dapat dianggap orang yang tidak memerlukan pertolongan Allah SWT.

Salah satu yang harus kita lakukan dalam kehidupan sebagai muslim adalah berdo'a kepada Allah SWT. Do'a bukan hanya menunjukkan kita merendahkan diri kepada Allah, tapi memang kita merasa betul-betul memerlukan bantuan dan pertolongan-Nya, karena Allah adalah segala-galanya, sedangkan kita amat memerlukan dan bergantung kepada-Nya. Salah satu dari sekian banyak do'a yang diajarkan Rasulullah kepada kita sebagaimana yang yang diriwayatkan oleh Ahmad, Muslim dan Nasa'i adalah:

Ya Allah, aku berlindung kepada-mu dari ilmu yang tak bermanfaat, dari hati yang tak khusyu' dan jiwa yang tak pernah merasa puas serta do'a yang tak terkabul" (Yani, 2000).

Empat permintaan tersebut rasanya penting untuk difahami agar dalam do'a yang kita panjatkan selalu dengan penghayatan dan kesungguhan, bukan sekedar kalimat-kalimat yang dihafal. Permintaan pertama adalah berlindung kepada Allah dari kemungkinan memiliki ilmu yang tidak bermanfaat, yakni ilmu yang tidak kita amalkan dan tidak mau kita ajarkan kepada orang lain. Ilmu yang bermanfaat adalah ilmu yang membuat kita semakin menyadari kebodohan diri kita sendiri lalu kita 96 
akan terus memperbanyaknya serta ilmu yang membuat kita semakin tawaddu' atau rendah hati bukan malah membuat kita menjadi takabbur (sombong). Di samping itu, ilmu yang bermanfaat juga membuat kita semakin dapat menempuh jalan hidup sebagaimana yang ditentukan Allah SWT. Karena itu, azab yang paling pedih dalam kehidupan akhirat adalah apabila orang mempunyai ilmu (alim) tapi tidak memanfaatkan ilmu itu sebagaimana mestinya.

Kedua, yang menjadi permintaan penting yang diajarkan Rasulullah SAW, adalah berlindung kepada Allah dari hati yang tak khusu'. Secara harfiyah, khusu' artinya tunduk, rendah dan takluk, ini berarti hati yang khusu' adalah hati yang merasa dekat dengan Allah karena tunduk, merendahkan diri dan takut kepada-Nya. Dari hati yang khusu' ini, akan lahir sikap dan prilaku yang tunduk dfan patuh kepada Allah SWT, sehingga orang yang hatinya khusu' akan selalu melaksanakan apa yang diperintahkan oleh Allah SWT, dan meninggalkan segala bentuk larangan-Nya dalam situasi dan kondisi yang bagaimanapun juga serta di manapun di berada.

Permintaan penting yang ketiga adalah berlindung kepada Allah dari jiwa yang tak pernah merasa puas, hal ini karena sebenarnya Allah SWT, telah memberikan kenikmatan kepada kita nikmat yang amat banyak, bahkan banyaknya nikmat itu sampai tidak bisa kita hitung satu persatu. Sedangkan permintaan keempat, di atara do'a penting yang harus kita panjatkan adalah berlindung kepada Allah dari kemungkinan do'a yang tidak terkabul. Beberapa hal yang berkaitan dengan nikmat di bawah ini akan dipaparkan dalam beberapa ayat Al-Qur'an.

Firman Allah dalam surat Ibrahim ayat 34:

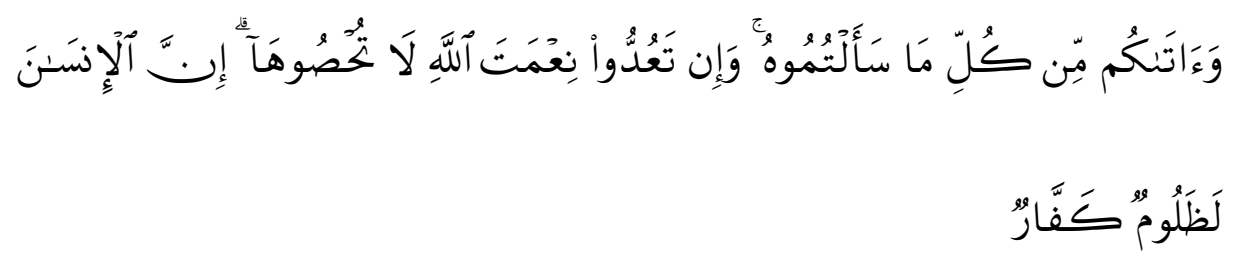

Dan dia Telah memberikan kepadamu (keperluanmu) dan segala apa yang kamu mohonkan kepadanya. dan jika kamu menghitung nikmat Allah, tidaklah dapat kamu menghinggakannya. Sesungguhnya manusia itu, sangat zalim dan sangat mengingkari (nikmat Allah). 
Ayat tersebut didahului oleh ayat-ayat sebelumnya yang berbicara tentang Allah yang mencipta dan mengatur ala mini, menciptakan manusia sebagai penghuni bumi; menurunkan hujan dari langit; mengeluarkan buah-buahan yang beraneka macam dari perut bumi sebagai rezeki bagi umat manusia, memudahkan bahtera berlkayar mengarungi samudera, menciptakan gunung-gunung dan sungai-sungai; menundukkan siang dan malam, serta matahari dan bulan, dan mendatangkan apa saja yang diminta ataupun yang tidak diminta oleh manusia. Segala yang disebutkan itu, merupakan nikmat-nikmat besar dari Allah, yang mencakup nikmat material dan immaterial (Q.S. Ibrahim 14: 32-33). (Faqih, 1996).

\section{Tujuan Pemberian Nikmat.}

Tujuan utama pemberian nikmat kepada manusia adalah untuk menjadi ujian atau cobaan, apakah mereka sanggup mensyukuri nikmat itu ataukah justru mengkufurinya. Hal ini sesuai dengan Firman Allah (Q.S.An-Naml: 40):

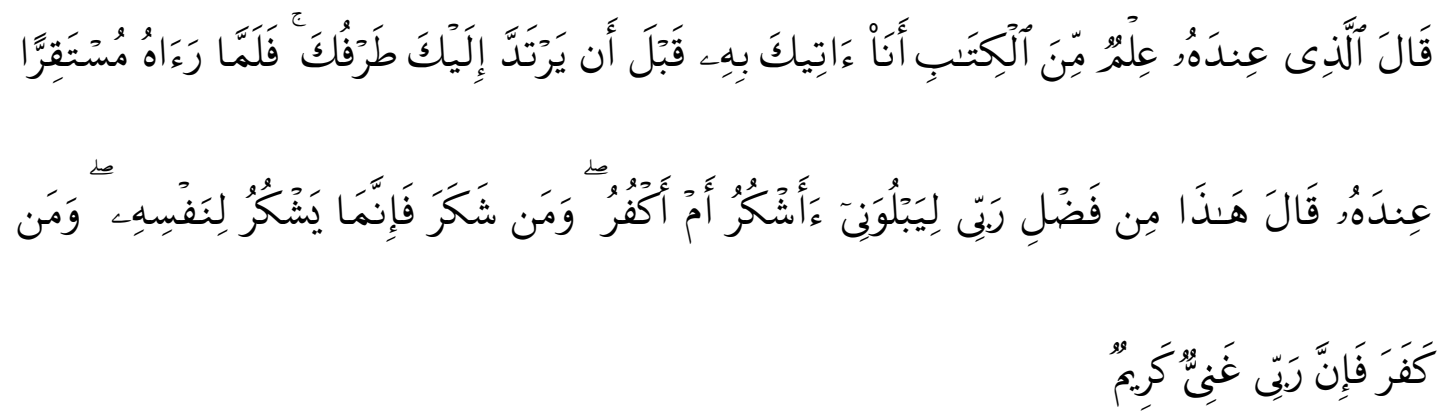

Berkatalah seorang yang mempunyai ilmu dari AI Kitab:"Aku akan membawa singgasana itu kepadamu sebelum matamu berkedip". Maka tatkala Sulaiman melihat singgasana itu terletak di hadapannya, iapun berkata: "Ini termasuk kurnia Tuhanku untuk mencoba Aku apakah Aku bersyukur atau mengingkari (akan nikmat-Nya). dan barangsiapa yang bersyukur Maka Sesungguhnya dia bersyukur untuk (kebaikan) dirinya sendiri dan barangsiapa yang ingkar, Maka Sesungguhnya Tuhanku Maha Kaya lagi Maha Mulia".

Bila manusia mensyukuri nikmat-nikmat yang dianugerahkan kepadanya, maka manfaat dari kesyukurannya itu akan kembali kepada dirinya, dan rizki dari Allah akan bertambah bahkan dilipatgandakan. Sebaliknya, bila manusia mengkufuri 
niukmat-nikmat-Nya, maka kekufurannya itu tidak akan mempengaruhi kekuasaan Allah sebagai penguasa mutlak dan pemilik sebenernya dari alam semesta ini.

Dalam surat Alim Imran ayat 97 Allah berfirman:

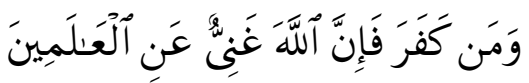

Barangsiapa mengingkari (kewajiban haji), Maka Sesungguhnya Allah Maha Kaya (Tidak memerlukan sesuatu) dari semesta alam.

Bahkan dengan kekufurannya itu, manusia makan mendapat adzab Allah yang demikian pebih. Hal ini seperti tersebut dalam Firman Allah (Q.S. Ibrahim: 7):

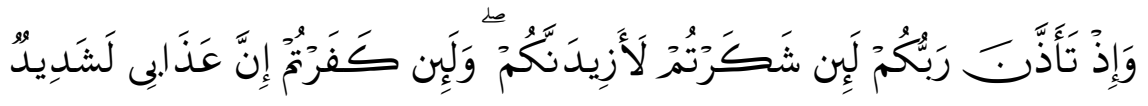

Dan (ingatlah juga), tatkala Tuhanmu memaklumkan; "Sesungguhnya jika kamu bersyukur, pasti kami akan menambah (nikmat) kepadamu, dan jika kamu mengingkari (nikmat-Ku), Maka Sesungguhnya azab-Ku sangat pedih".

Dari sekian banyak nikmat yang Allah anugerahkan kepada manusia, ada tiga nikmat inti dan penting pada diri manusia yang seringkali tidak disyukuri dan disalahfungsikan kegunaannya. Nikmat-nikmat itu ialah pendengaran (as-Sam'u), penglihatan (al-Basharu), dan hati/akal fikiran (Al-Fu'adu).

\section{Larangan Membiarkan Kelamahan}

Telah dijelaskan di atas bahwa Islam sangat menganjurkan umatnya untuk berusaha dan bekerja sehingga menjadi orang yang kuat dalam berbagai hal, Baik iman, jiwa, raga, badan,harta, dan lain-lain.

Kelemahan seseorang berawal dari kemalasannya Orang yang bodoh malas mencari Ilmu; orang yang lemah badannya karena ia tidak rajin berolah raga, orang yang miskin hartanya karena ia tidak mau bekerja, dan lain-lain.

Setiap orang harus berusaha untuk mengubah segala kelemahannya yang ada pada dirinya karena Allah SWT. Tidak akan mengubahnya. (Ar-Ra'du :11). 


\section{Larangan untuk menyatakan "kalau" (seandainya begini dan begitu pasti halnya begini)}

Dalam berusaha, tidak dapat dipastikan bahwa selamanya berhasil, Suatu waktu, seseorang pasti mendapatkan kegagalan dalam mengahadapi keadaan seperti itu, Islam menganjurkan untuk menyerahkan menjadi kehendak-Nya dan manusia hanyalah berusaha untuk beriktiar. Pernyataan "kalau begini dan begitu" merupakan godaan setan untuk mendahului kehendak Allah SWT. Tidak menghendaki keberhasilannya

Pemahaman Al- Hadis: Orang mukmin yang kuat, baik dalam keimanan, badan, kekayaan, dan lain-lain lebih baik dan lebih dicintai Allah daripada mukmin yang lemah, Seorang mukmin harus berusaha untuk memanfaatkan kesempatan terhadap segala sesuatu yang bermanfaat, yang dengan mengisi waktunya dengan aktivitas yang memberikan manfaat.

Setelah berusaha dengan baik, seorang mukmin harus bertawakal, dan berdoa kepada Allah SWT. Dia lah yang berperan dalam menentukan sesuatu, sedangkan manusia hanyalah beriktiar.

Jika ditimpa kegagalan, seorang mukmin tidak boleh berkata, "Kalau aku berbuat begini, pasti begini dan begitu, "Akan tetapi, hendaknya ia berkata : "Allah SWT, telah menentukan dan Allah menghendaki hal itu."Karena pernyataan "kalau" berarti mendahului kehendak Allah dan termasuk salah satu perbuatan setan.

\section{KESIMPULAN}

Dari uraian di atas, dapat disimpulkan sebagai berikut:

1. Bahwa usaha yang baik adalah, usaha yang dilakukan oleh seseorang dengan tangannya sendiri

2. Dalam melakukan usaha seseorang harus mempunyai etika (cara-cara yang baik), sesuai dengan ajaran Islam;

3. Dalam mencari usaha tidak boleh dilakukan dengan cara yang batil;

4. Tidak boleh dzalim dalam bekerja maupun usaha lainnya. 


\section{PUSTAKA ACUAN}

A Syaikh Abdur Razzaq bin Abdul Muhsin Al-"Abbad Al Badr, 2006. Dalam Asbab Ziyadati al-Imani wa nuqshanihi, yang diterjemahkan oleh Ahmad S Marzuki. Yogyakarta: Media Hidayah.

Abdul Baqi, Muhammad Fuad Al-Lu'lu wa al-Marjan, 1996. Terjemah H. Salim Bahreisy. Surabaya: Bina Ilmu.

Ahmad Mudjab Mahalli, 2004. Hadits-hadits Muttafaq 'alaih bagian Munakahat dan Mu'amalat. Jakarta: Prenada Media.

Ahmad Yani, 2000. Empat Permintaan. Jakarta: Buletin Khairu Ummah, LPPD Khairu Ummah.

Ash-Shiddieqi, M, Hasbi dkk, 1990. Al-Qur'an dan Terjemahnya. Jakarta: Depag RI.

H. Abdullah Faqih S, 1996. Hubungan Ibadah dengan Syukur Nikmat. Jakarta: Bultin Dakwah, Dewan Dakwah Islamiyah Indonesia.

H. Hamzah Ya'kub, 2003. Etos Kerja Islami, petunjuk pekerjaan yang halal dan Haram dalam Syari'at Islam. Jakarta: Media Ilmu Jaya.

Imam Nawawi, 2001. Syarah Hadits Arbain, Pensyarat Ibnu Daqiq al 'Ied, terjemah Muhammad Thalib. Yogyakarta: Media Hidayah.

Muhammad, Abu Bakar, 1995. Hadits Tarbiyah. Surabaya: Al-Ikhlas.

Ringkasan penulis dari Manajemen Iman (Asbab Ziyadah al-Iman wa nuqshanih, Karya Syaikh Abdur Razzaq bin Abdul Muhsin Al-Abbad Al Badr, dari hal 15 sampai 95. 
Jurnal Islamiconomic Vol.6 No.1 Januari - Juni 2015 